\title{
HAMBATAN KOMUNIKASI DAN STRES ORANGTUA SISWA TUNARUNGU SEKOLAH DASAR
}

\author{
Indah Damayanti, Sri Hadiati Purnamasari \\ Fakultas Psikologi Universitas Islam Negeri Sultan Syarif Kasim Riau \\ Email: indah.damayanti@uin-suska.ac.id
}

\begin{abstract}
Constraints in communication are generally experienced by parents with deaf children in elementary school age. The inability of children to hear and the lack of vocabulary of the children causes difficulties in understanding and conveying messages between parents and children. This causes the need for parents to convey and receive messages from children not achieved perfectly and cause stress. This study aimed to determine the relationship between barriers to communication with stress in parents with deaf children at primary school SLBN Pembina Pekanbaru. This study used correlational method. This research had 42 participants and used the instruments scale of communication barriers scale (Fajar, 2009) and stress scale based on Sarafino's (1997) theories of stress and symptoms. The results showed the positive correlation of $0.819(p<0.01)$.
\end{abstract}

Key words: communication barriers, stress, parents with deaf children.

\begin{abstract}
Abstrak
Hambatan dalam berkomunikasi umumnya banyak dialami oleh orangtua dengan anak tunarungu, khususnya di usia sekolah dasar. Ketidakmampuan anak dalam mendengar dan kurangnya kosakata yang dikuasai anak menyebabkan terjadi kesulitan dalam memahami maupun menyampaikan pesan antara orangtua dan anak. Hal ini menyebabkan kebutuhan orangtua untuk menyampaikan dan menerima pesan dari anak tidak tercapai secara sempurna dan menimbulkan stres. Penelitian ini bertujuan untuk mengetahui hubungan antara hambatan komunikasi dengan stres pada orangtua yang memiliki anak tunarungu tingkat sekolah dasar di SLBN Pembina Pekanbaru. Metode dalam penelitian ini menggunakan pendekatan kuantitatif dengan desain penelitian korelasional. Penelitian ini melibatkan 42 orang tua SLBN Pembina Pakanbaru. Instrumen penelitian ini adalah skala hambatan komunikasi (Fajar, 2009) dan skala stres (Sarafino, 1997). Hasil korelasi menunjukkan nilai $r=0,819(\mathrm{p}=<0,01)$, artinya terdapat hubungan positif antara hambatan komunikasi dengan stres pada orangtua yang memiliki anak tunarungu tingkat sekolah dasar di SLBN Pembina Pekanbaru.
\end{abstract}

Kata kunci: Hambatan Komunikasi, Stres, Orangtua yang memiliki anak tunarungu.

\section{PENDAHULUAN}

Manusia merupakan makhluk sosial yang memiliki kebutuhan dan kemampuan untuk berkomunikasi dengan orang lain. Komunikasi merupakan proses yang sangat penting di dalam kehidupan seorang individu. Melalui komunikasi seseorang atau 
beberapa orang, kelompok, organisasi, dan masyarakat menciptakan dan menggunakan informasi agar terhubung dengan lingkungan dan orang lain (Ruben dan Stewart, 2006), salah satu contohnya ialah komunikasi yang terjadi antara orangtua dan anak.

Komunikasi antara orangtua dan anak merupakan komunikasi yang paling banyak dilakukan, karena orangtua merupakan sosok terdekat bagi anak. Orangtua memiliki peranan penting dalam pembentukan karakter dan kepribadian anak. Peranan lain yang tidak kalah pentingnya yaitu membantu anak untuk mengembangkan kemampuan komunikasinya. Orangtua mengajarkan seorang anak bagaimana cara berkomunikasi dengan orang lain baik secara verbal maupun non verbal. Sebagai contoh, ketika anak masih kecil biasanya saat sedang menyusui, memandikan, menyuapi, ataupun saat mengajak anaknya bermain ibu akan mengajak anaknya berbicara ataupun bercerita.

Hal yang penting dalam komunikasi antara orangtua dan anak yaitu bagaimana cara orangtua dapat berkomunikasi dengan seefektif mungkin. Menurut Tubss dan Moss (dalam Mulyana, 2005), komunikasi dikatakan efektif apabila orang berhasil menyampaikan apa yang dimaksudkannya atau komunikasi dinilai efektif apabila rangsangan yang disampaikan dan dimaksudkan oleh pengirim atau sumber, berkaitan erat dengan rangsangan yang ditangkap dan dipahami oleh penerima. Melalui komunikasi yang efektif orangtua mampu menyampaikan sesuatu kepada anak tentang apa yang dirasakan, apa yang dilihat dan apa yang didengar, demikian juga sebaliknya dengan anak. Namun bagi orangtua yang mempunyai anak tunarungu dengan keterbatasan dalam pendengaran komunikasi antara orangtua dan anak akan cenderung mengalami lebih banyak hambatan.

Berdasarkan pengalaman peneliti yang pernah mengajar di salah satu sekolah luar biasa (SLB) di Pekanbaru, ditemukan hambatan dan kesulitan yang dialami oleh orangtua dalam berkomunikasi dengan anak tunarungu, khususnya anak-anak tunarungu yang masih duduk di bangku sekolah dasar (SD). Berdasarkan observasi yang peneliti lakukan selama menjadi guru di SLB, melalui keluhan yang disampaikan oleh orangtua, hambatan yang dialami oleh orangtua yang memiliki anak tunarungu, antara lain yaitu orangtua mengeluh bahwa mereka seringkali tidak memahami apa yang dikatakan oleh anak, orangtua tidak bisa menggunakan komunikasi verbal melalui tulisan, karena anak belum bisa memahami makna tulisan dan kurangnya penguasaan kosakata, dan hambatan terbesar yaitu orangtua tidak bisa menyampaikan pesan dan maksud kepada anak karena anak tidak mengerti apa yang disampaikan oleh orangtua.

Penelitian yang dilakukan oleh Negeri (2013) menemukan bahwa kesulitan lain dalam berkomunikasi menyebabkan perbedaan pemahaman antara orangtua dan anak, ini juga merupakan kesulitan yang dialami oleh subjek yang memiliki anak tunarungu, yaitu kesulitan untuk memahami keinginan anak. Ketidakmampuan dalam menyampaikan pikiran, perasaan, gagasan, kebutuhan dan kehendak pada orang lain tersebut menimbulkan dampak kebutuhan tidak terpuaskan secara sempurna (Indriyani, 
2004). Suatu kebutuhan yang tidak terpenuhi dan kebutuhan tersebut bisa saja kebutuhan fisiologis, psikologis, sosial, lingkungan, perkembangan, spiritual, atau kebutuhan kultural merupakan faktor-faktor pemicu timbulnya stres (Potter dan Perry, 2005).

Tidak terpuaskannya kebutuhan secara sempurna akibat hambatan dalam berkomunikasi dampaknya berpengaruh pada tingkat stres. Berdasarkan penelitian yang dilakukan oleh Gunawati, Hartati dan Listira (2006), efektivitas komunikasi memiliki hubungan dengan tingkat stres. Semakin efektif komunikasi yang terjalin, maka tingkat stres semakin rendah. Penelitian ini sejalan dengan penelitian yang dilakukan oleh Indrawati (2007) yang menyimpulkan bahwa keterampilan komunikasi mempengaruhi tinggi rendahnya tingkat stres. Penelitian lain juga menunjukkan bahwa komunikasi dapat mempengaruhi tingkat stres yaitu penelitian yang dilakukan oleh Julianti dan Yulia (2015). Hasil penelitian tersebut menunjukkan adanya hubungan negatif antara komunikasi dan tingkat stres. Artinya, semakin tinggi kemampuan individu dalam berkomunikasi, maka akan semakin rendah tingkat stres yang dialami.

Komunikasi adalah suatu proses penyampaian dan penerimaan lambang yang mengandung arti, baik berupa informasi, pemikiran, pengetahuan dan lainnya, dari komunikator ke komunikan. Komunikasi merupakan faktor yang penting dalam hubungan interpersonal (Walgito, 2009). Lunandi (1992) menyatakan bahwa komunikasi adalah kegiatan menyatakan suatu gagasan dan menerima umpan balik dengan cara menafsirkan pernyataan tentang gagasan dan pernyataan orang lain. Komunikasi tidak hanya sekedar menyampaikan pesan dari komunikator ke komunikan, tetapi ada umpan balik dari pesan yang disampaikan.

Menurut Tubss dan Moss (dalam Mulyana, 2005), komunikasi dikatakan efektif apabila orang berhasil menyampaikan apa yang dimaksudkannya atau komunikasi dinilai efektif apabila rangsangan yang disampaikan dan dimaksudkan oleh pengirim atau sumber, berkaitan erat dengan rangsangan yang ditangkap dan dipahami oleh penerima. Effendy (2003) menyatakan beberapa ahli komunikasi mengatakan bahwa tidaklah mungkin seseorang melakukan komunikasi yang sebenar-benarnya efektif. Ada banyak hambatan yang dapat merusak komunikasi. Segala sesuatu yang menghalangi kelancaran komunikasi disebut sebagai gangguan (noise). DeVito (2009) menyatakan bahwa hambatan komunikasi memiliki pengertian bahwa segala sesuatu yang dapat mendistorsi pesan atau hal apapun yang menghalangi penerima menerima pesan.

Dari pengertian para ahli dapat disimpulkan bahwa hambatan komunikasi adalah segala bentuk gangguan yang terjadi di dalam proses penyampaian dan penerimaan suatu pesan dari individu kepada individu yang lain yang disebabkan oleh faktor lingkungan maupun faktor fisik dan psikis dari individu itu sendiri.

Ada hambatan dalam komunikasi, yaitu: 1) Hambatan dari pengirim pesan, misalnya pesan yang akan disampaikan belum jelas bagi dirinya atau pengirim pesan, 
hal ini dipengaruhi oleh perasaan atau situasi emosional sehingga mempengaruhi motivasi, yaitu mendorong seseorang untuk bertindak sesuai keinginan, kebutuhan atau kepentingan, 2) Hambatan dalam penyandian/simbol. Hal ini dapat terjadi karena bahasa yang dipergunakan tidak jelas sehingga mempunyai arti lebih dari satu, simbol yang digunakan antara si pengirim dengan si penerima tidak sama, atau bahasa yang dipergunakan terlalu sulit, 3) Hambatan media, adalah hambatan yang terjadi dalam penggunaaan media komunikasi, misalnya gangguan suara radio sehingga tidak dapat mendengarkan pesan dengan jelas. 4) Hambatan dalam bahasa sandi. Hambatan terjadi dalam menafsirkan sandi oleh si penerima, 5) Hambatan dari penerima pesan. Misalnya kurangnya perhatian pada saat menerima/ mendengarkan pesan, sikap/ prasangka/ tanggapan yang keliru dan tidak mencari informasi lebih lanjut (Fajar, 2009).

Wursanto (2005) meringkas hambatan komunikasi terdiri dari tiga macam, yaitu: 1) Hambatan yang bersifat teknis, yang merupakan hambatan yang disebabkan oleh faktor kurangnya sarana dan prasarana yang diperlukan dalam proses komunikasi, penguasaan teknik dan metode berkomunikasi yang tidak sesuai, kondisi fisik yang tidak memungkinkan terjadinya proses komunikasi yang dibagi menjadi kondisi fisik manusia, kondisi fisik yang berhubungan dengan waktu atau situasi/ keadaan, dan kondisi peralatan. 2) Hambatan semantik, yang disebabkan oleh kesalahan dalam menafsirkan, kesalahan dalam memberikan pengertian terhadap bahasa (kata-kata, kalimat, kode-kode) yang dipergunakan dalam proses komunikasi. 3) Hambatan perilaku atau hambatan kemanusiaan, yang disebabkan berbagai bentuk sikap atau perilaku, baik dari komunikator maupun komunikan. Hambatan perilaku tampak dalam berbagai bentuk, seperti: pandangan yang sifatnya apriori, prasangka yang didasarkan pada emosi, suasana otoriter, ketidakmauan untuk berubah, sifat yang egosentris.

Bishop (1994) menyatakan bahwa stres adalah interaksi antara individu dengan lingkungan, menimbulkan suatu tekanan dalam diri individu akibat adanya suatu tuntutan yang melebihi batas kemampuan individu untuk menghadapinya dan memberikan respon fisik maupun psikis terhadap tuntutan yang dipersepsi. Pengertian ini menekankan adanya tuntutan pada diri seseorang yang melebihi kemampuannya, dan adanya proses persepsi yang dilakukan oleh individu terhadap kejadian atau hal di lingkungan yang menjadi sumber stres.

Stres adalah suatu kondisi adanya tekanan fisik dan psikis akibat adanya tuntutan dalam diri dan lingkungan (Rathus \& Nevid, 2002). Pernyataan tersebut berarti bahwa seseorang dapat dikatakan mengalami stres, ketika seseorang tersebut mengalami suatu kondisi adanya tekanan dalam diri akibat tuntutan-tuntutan yang berasal dari dalam diri dan lingkungan.

Stres merupakan kondisi disebabkan oleh transaksi antara individu dengan lingkungannya yang menimbulkan jarak antara tuntutan-tuntutan yang berasal dari sumber daya sistem biologis, psikologis, maupun sosial (Cox, 1978; Lazarus \& 
Folkman, 1984; Mechanic, 1976; Singer \& Davidson, 1986; Stotland, 1987; Trumbull \& Aplley, 1986 dalam Sarafino, 1997). Lazarus dan Folkman (1984) mendefinisikan stres sebagai suatu kondisi yang muncul pada individu ketika menganggap suatu kejadian sebagai suatu hal yang mengancam dan menyulitkan.

Aspek-aspek stres ada dua, yaitu: aspek biologis dan aspek psikologis. Aspek biologis dari stres berupa gejala fisik. Gejala fisik dari stres yang dialami individu antara lain: sakit kepala, gugup, urat tegang, gangguan tidur, gangguan pencernaan, gangguan makan, gangguan kulit dan produksi keringat yang berlebihan. Aspek psikologis stres berupa gejala psikis. Gejala psikis dari stres antara lain: Gejala emosi, yaitu kondisi stres dapat menganggu kestabilan emosi individu. Individu yang mengalami stres akan menunjukkan gejala merasa sedih, mudah marah, kecemasan yang berlebihan terhadap segala sesuatu, dan depresi. Gejala kognitif, yaitu kondisi stres dapat menganggu proses pikir individu. Individu yang mengalami stres cenderung mengalami gangguan daya ingat menurun, lemah dalam menyelesaikan masalah, takut gagal, gangguan perhatian dan konsentrasi. Gejala tingkah laku, yaitu kondisi stres dapat mempengaruhi tingkah laku sehari-hari yang cenderung negatif sehingga menimbulkan masalah dalam hubungan interpersonal, seperti menarik diri dari keluarga, kehilangan minat, emosi yang meledak, dan agresi (Sarafino, 1997).

Dari temuan masalah di lapangan dan analisis terhadap temuan-temuan pada penelitian-penelitian terkait dan teori yang ada, peneliti melihat indikasi adanya hubungan antara hambatan komunikasi dan stress pada orangtua yang memiliki anak tunarungu di SDLBN Pembina Pekanbaru. Untuk itu, peneliti melakukan penelitian terhadap dugaan tersebut.

\section{METODE}

Patispan: partisipan penelitian ini sebanyak 42 orangtua yang memiliki anak tunarungu di SDLBN Pembina Pekanbaru.

Teknik pengumpulan data pada penelitian ini menggunakan skala psikologi. Dalam penelitian ini peneliti menggunakan dua skala, yaitu skala hambatan komunikasi yang peneliti susun dari teori hambatan komunikasi dari Fajar (2009) dan skala stres yang diturunkan dari teori Sarafino (1997).

\section{HASIL}

Penelitian ini bertujuan untuk mengetahui hubungan antara hambatan komunikasi dan stres pada orangtua yang memiliki anak tunarungu. Berdasarkan hasil analisis korelasi Product Moment yang dilakukan, ditemukan bahwa hambatan komunikasi dan 
stres pada orangtua yang memiliki anak tunarungu tingkat sekolah dasar di SDLBN Pembina Pekanbaru memiliki korelasi yang positif, sebesar 0,819 ( $\mathrm{p}<0,01)$. Artinya, semakin besar hambatan komunikasi yang terjadi antara orangtua dan anak, maka semakin tinggi tingkat stres pada orangtua yang memiliki anak tunarungu tingkat sekolah dasar di SDLBN Pembina Pekanbaru. Begitu pula sebaliknya, semakin kecil hambatan komunikasi yang terjadi antara orangtua dan anak, maka semakin rendah tingkat stres pada orangtua yang memiliki anak tunarungu tingkat sekolah dasar di SDLBN Pembina Pekanbaru.

\section{PEMBAHASAN}

Hasil penelitian yang menunjukkan adanya hubungan antara hambatan komunikasi dan stres ini sesuai dengan penelitian yang dilakukan Indriyani (2004) yang menyatakan bahwa ketidakmampuan dalam menyampaikan pikiran, perasaan, gagasan, kebutuhan dan kehendak pada orang lain tersebut menimbulkan dampak kebutuhan tidak terpuaskan secara sempurna yang berujung pada perasaan tertekan atau stres.

Hambatan dalam berkomunikasi ini dapat berupa kesalahpahaman orang tua dengan kata-kata yang disampaikan oleh anak, bahasa isyarat yang digunakan oleh anak tidak dimengerti oleh orang tua, anak tidak mengerti pesan yang disampaikan oleh orangtua, serta kurangnya kemampuan anak dalam mendengar, berbicara, dan menulis yang menyebabkan orangtua sulit menyampaikan pikiran dan perasaan kepada anak, serta orangtua juga kesulitan dalam memahami pikiran dan perasaan anak. Hal ini sejalan dengan pernyataan Sastrawinata (2013) yang mengatakan ketidakmampuan anak mendengar menyebabkan kesulitan berkomunikasi. Anak yang menyandang tunarungu tidak mampu menangkap pesan melalui suara dari individu normal dengan baik, sebaliknya individu normal seringkali tidak mengerti bagaimana cara menyampaikan pesan kepada anak yang menyandang tunarungu.

Orangtua yang memiliki anak tunarungu cenderung mengalami tekanan secara fisik dan psikologis, seperti sakit kepala, gugup, urat tegang, merasa sedih, cemas berlebihan, mudah marah, dan daya ingat menurun. Dogan (2010) menemukan bahwa orangtua (terutama ibu) yang memiliki anak dengan gangguan pendengaran memiliki tingkat level stres, depresi, dan sifat kecemasan yang lebih tinggi daripada orangtua dari anak dengan pendengaran normal. Namun demikian, tidak ada orangtua anak tunarungu pada SDLBN Pembina Pekanbaru yang mengalami stres berat.

Hambatan komunikasi bukanlah satu-satunya faktor yang mempengaruhi stres pada orangtua yang memiliki anak tunarungu. Terdapat faktor-faktor lainnya seperti ketakutan orang tua akan masa depan anak saat dewasa, merasa rendah diri terhadap 
lingkungan, dan faktor-faktor lainnya yang dapat mempengaruhi stres pada orangtua yang memiliki anak tunarungu.

\section{DAFTAR PUSTAKA}

Arikunto, Suharsini. 2002. Prosedur Penelitian Suatu Pendekatan Edisi Revisi V, Jakarta: Penerbit Rineka Cipta

Azwar, Saifuddin. 2010. Penyusunan Skala Psikologi. Yogyakarta: Penerbit Pustaka Pelajar

Bishop, G. D. 1994. Health Psychology: Integrating Mind and Body. Singapore: Allin and Bacon.

DeVito, Joseph A. (2009). Komunikasi Antarmanusia (alih bahasa: Ir. Agus Maulana M.S.M.). Tangerang: Karisma Publishing Group

Dogan, M. 2010. Comparison Of The Parents Of Children With And Without Hearing Loss In Terms Of Stress, Depression, And Trait Anxiety. International Journal of early Childhood Special Education (INT-JECSE), 2:3

Efendi, Mohammad. 2006. Pengantar Psikopedagogik Anak Berkelainan. Jakarta: Bumi Aksara

Effendy, Onong Uchjana. 2003. Ilmu, Teori dan Filsafat Komunikasi. Bandung: PT. Citra Aditya Bakti.

Fajar, Marhaeni. 2009. Ilmu Komunikasi Teori dan Praktek EdisiPertama. Yogyakarta: Graha Ilmu

Gunawati, Rindang, Sri Hartati dan Anita Listiara. 2006. Hubungan Antara Efektivitas Komunikasi Mahasiswadosen Pembimbing Utama Skripsi dengan Stres Dalam Menyusun Skripsi Pada Mahasiswa Program Studi Psikologi Fakultas Kedokteran Universitas Diponegoro. Jurnal Psikologi Vol.3 No. 2, Desember2006. Fakultas Psikologi, Universitas Diponegoro

Hadi, Sutrisno. 2004. Statistik. Yogyakarta: Penerbit Andi

Indrawati, Lisna. 2007. Hubungan Antara Keterampilan Komunikasi Interpersonal Perawat dengan Pasien dan Stress Kerja Perawat. Skripsi. Yogyakarta: Fakultas Psikologi, Universitas Sanata Dharma

Indriyani, Faridah. 2004. Pengasuhan Orang Tua Terhadap Anak Tunarungu (Studi Kasus di SLB Nurasih Ciputat). Skripsi. Jakarta: Fakultas Psikologi, UIN Syarif Hidayatullah 
Julianti, Rina dan Aida Yulia. Hubungan Komunikasi Antara Mahasiswa Dan Dosen Pembimbing Skripsi Dengan Stres Dalam Menyusun Skripsi Pada Mahasiswa S 1 Keperawatan Stikes Ranah Minang. Jurnal Ilmiah Ilmu Pendidikan Vol. XV No. 2, November 2015. Fakultas Ilmu Pendidikan, Universitas Negeri Padang

Lazarus, S. R. \&Folkman, Susan. 1984. Stress, Appraisal, and Coping. New York: Springer Publishing Company.

Lunandi, A.G. 1992. Meningkatkan Efektivitas Komunikasi Atar Pribadi. Yogyakarta: Kanisius

Margunsong, Frieda. 2009. Psikologi dan Pendidikan Anak Berkebutuhan Khusus. Depok: Lembaga Pengembangan Sarana Pengukuran dan Pendidikan Psikologi (LPSP3) Fakultas Psikologi Universitas Indonesia (FPUI)

Mulyana, Dedi. 2005. Ilmu Komunikasi : Suatu Pengantar. Bandung : Remaja Rosda Karya

Negeri, Citra Bunga. 2013. Subjective Well Being pada Ibu yang Memiliki Anak Tuna Rungu. Jurnal Ilmiah Mahasiswa Universitas Surabaya Vol: 2 (2). Fakultas Psikologi, Universitas Surabaya

Potter, P.A dan Perry. 2005. Buku Ajar Fundamental Keperawatan Konsep, Proses, dan Praktik Edisi 4. Jakarta: EGC

Putry, Dian Andhyka. 2013. Aktivitas Komunikasi Orang Tua dengan Anak Tunarungu (Studi Kasus Aktivitas Komunikasi Verbal dan Nonverbal Orang Tua dengan Anak Tunarungu di SLB Negeri 017700 Kota Kisaran). Jurnal Ilmu Komunikasi Vol.1 (3). Fakultas Ilmu Komunikasi, Universitas Sumatera Utara

Rathus, S. A. \& Nevid, J. S. 2002. Psychology and The Challenge of Life: Adjustment in The New Millenium. Eight Edition. Danver: John Willey \& Sons, Inc.

Ruben, Brent D \& Lea P. Steward. 2006. Komunikasi dan Perilaku Manusia. Jakarta : PT. Rajagrafindo Persada

Sarafino, E.P. 1997. Health Psychology Third Edition. Canada: John Wiley \& Sons.

Sinaga, Deniaty. 2015. Pola Komunikasi Orang Tua Tunarungu Dengan Anaknya Yang

Memiliki Pendengaran Normal. Yogyakarta: Fakultas Ilmu Pendidikan, Pendidikan Luar Biasa, Universitas Pendidikan Indonesia.

Smet, bart. 1994. Psikologi kesehatan. Jakarta: Gramedia Widiasarana Indonesia.

Somantri, Sutjihati T. 2007. Psikologi Anak Luar Biasa. Bandung: Refika Aditama Sugiyono, 2013. Metode Penelitian Kuantitatif Kualitatif dan R\&D. Bandung : Alfabeta Sugiyono, 2011. Statistika Untuk Penelitian. Bandung: Penerbit Alfabeta 
Syatriani, Revi. 2011. Hubungan antara Kemampuan Komunikasi dengan Kemandirian pada Remaja Tunarungu. Skripsi. Fakultas Psikologi, Universitas Gunadarma

Variani, Ludfia Ida. 2011. Pelatihan Sistem Isyarat Bahasa Indonesia (SIBI) Terhadap Peningkatan Kemampuan Komunikasi Orang Tua dengan Anak Tunarungu. Ringkasan Tesis. Malang: Fakultas Psikologi, Universitas Muhammadiyah Malang

Walgito, Bimo. 2010. Pengantar Psikologi Umum. Yogyakarta: C.V. Andi Offset

Wursanto, I. (2005). Dasar-dasar Ilmu Organisasi. Yogyakarta: CV. Andi Offset. 